\title{
Ngapartji ngapartji ninti and koorliny karnya quoppa katitjin (Respectful and ethical research in central Australia and the south west)
}

\begin{tabular}{c|c}
$\begin{array}{c}\text { Jennie Buchanan } \\
\text { Murdoch University } \\
\text { jenreflective@gmail.com }\end{array}$ & $\begin{array}{c}\text { Len Collard } \\
\text { University of Western Australia } \\
\text { leonard.collard@uwa.edu.au }\end{array}$ \\
\hline & Dave Palmer \\
Murdoch University \\
D.Palmer@murdoch.edu.au
\end{tabular}

Keywords: marlpara (friend/colleague), ngapartji ngapartji (reciprocity), birniny (digging and inquiring), kulini (listening), dabakarn dabakarn (going slowly)

\begin{abstract}
This paper is set out as a conversation between three people, an Indigenous person and two non-Indigenous people, who have known and worked with each other for over 30 years. This work has involved them researching with communities in central Australia and the south west of Western Australia. The discussion concerns itself with ideas and practices that come from three conceptual traditions; English, Noongar and Pitjantjatjara to talk about how to build ngapartji ngapartji ("you give and I give in return", in Pitjantjatjara), karnya birit gnarl (respectful and kind ways of sweating/working with people, in Noongar), between marlpara ("colleagues", in Pitjantjatjara) and involving warlbirniny quop weirn (singing out to the old people, in Noongar).
\end{abstract}

\section{Kura katitj (Introduction and background)}

The history of outsiders carrying out research with Indigenous Australians is long and often vexed. To say that Indigenous communities do not often benefit from the work of researchers is perhaps an understatement. Although approved by the ethical protocols of universities, much research that is undertaken "on" Indigenous people, Indigenous lands and Indigenous knowledge maintains the longstanding model of "excavating" information, artifacts and insights.

This reflects a long and lasting history where the vested interests of outsiders (like government, business, universities, even non-government organisations) usurp the goals and aspirations of Indigenous communities. It also reflects the fact that there are fewer areas of research in Australia where outsiders have invested so poorly in the capability and ethical practices of those they "send" to work with Indigenous communities.

This chapter will provide a series of contemplations from a Noongar ${ }^{1}$ man and two nonIndigenous people whose research work with communities routinely sees them confronting

1 We use the term Noongar to refer to those - living and who have passed away - with longstanding cultural affiliations and connections to the south-west corner of Western Australia. 
tensions, paradoxes and ethical challenges. It takes the form of a dialogue where each draws together their experience as researchers. Moving between central Australia and the south west of Western Australia, this dialogue opens up a conversation across three knowledge domains: academic English, Noongar and Western Desert systems such as Pitjantjatjara. Using conceptual and cultural frameworks from across these systems we attempt to talk about how to build ngapartji ngapartji ("you give and I give in return", in Pitjantjatjara), karnya birit gnarl (respectful and kind ways of sweating/working with people, in Noongar), between marlpara ("colleagues", in Pitjantjatjara) and involving warlbirniny quop weirn (singing out to the old people, in Noongar). To support this discussion we also draw on work written by some of our Māori colleagues and friends.

The decision to write as a dialogue between three people may be seen as a little wam (strange) to some. We have chosen to do it in a conscious attempt to "unsettle" the convention of creating a "voice" that is singular, authoritative and self-assured (see Freire, 1986; Westoby \& Dowling, 2013). In part, writing as a dialogue reflects the critical part that gnulla wangkiny in Noongar or nganana tjunguringkula waakaripai in Pitjantjatjara ("we go along talking and yarning together") plays in Indigenous Australian communities. It also reflects our desire to more honestly demonstrate the value of "yarning" (Bessarab \& Ng'andu, 2010; Barlo, 2017).

We will write this in a way that is closest to how the ideas came to be, as a series of observations and questions, forged through what we have read, tested and experienced. We will also write it in a way that pays respect to and rightfully tries to honour Indigenous ontological, epistemological and conceptual traditions. Although we write in English we will also draw upon Noongar and Pitjantjatjara language and conceptual ideas.

The piece also reflects the fact that the three authors have a long history of having yarns like this. We have known each other for more than thirty years, worked on research together, travelled often and learnt much from one another. In addition, in November of 2017 and specifically to help us prepare this paper, we sat down and recorded two yarns in Canberra and out at Boyagin Rock near Brookton in Western Australia.

Our style may be unsettling for some but as Muecke (2004) points out, Aboriginal frames have long had to endure an unfair distance from most recognized philosophy. This is despite the fact that they have long had much to offer (see Buchanan et al., 2016).

\section{Ngearn noonook, nguntu palya (Introducing each other)}

Dave: Len, can we start our discussion about research ethics by getting you to talk about first steps? We have this yarn on Noongar boodjar (Noongar country). As we begin the process of "travelling" from Noongar country to central Australia, what would you say about how we do this as "ethical researchers"?

Len: Well if wam (outsiders in Noongar) are yaarl koorliny gnulla boodjar (coming to our country in Noongar), one of the first things we would expect them to do is to "sing out" to the old people, those who have passed away and are now the spirit of the lands and sense of the place (Collard, 2007). You need to call out to ancestors, to moort (family in Noongar) about who you are and what your intentions are.

We do this out of respect to the people from that place. It also helps make us safe. Crucially it makes it clear to people from the area that whatever we might think about the ethical or right way to do things in our own area we also understand that the particular character and form of ethical behaviour shifts from place to place. This last point is important to make before we go too much further. Although we will make some observations, we don't want readers to mistake 
our main point, which is that ethical research is different from country to country and Indigenous group to Indigenous group.

So let's do this to our Anangu² moort or waltja (family, in Pitjantjatjara).

Kaya Anangu bidi. Nguntu palya? Gnulla koorbal karnya barminy gnulla nidja koorliny yeye nyinniny. Gnullak Noongar katitjin Anangu baranginy boollah katitjin bidi. Nidja Noongar boodjar noonook nyinniny. Anangu boordier nidja boojar, koora, yeye boorda. Gnulla koorbal boolah warlbirniny weirn.

(Hello to our Anangu bosses. Are you good? We write this while sitting in Noongar country. We believe it is worth remembering that Anangu have contributed much to cultural and economic life in central Australia as Noongar have in the south west of Australia. We recognise Anangu as bosses for their knowledge and language. We will go along picking our way through knowledge with a respectful feeling in our gut.)

Jen: Len, I am reminded of what your friend, colleague and Anangu maaman (father in Pitjantjatjara), Barry Judd, has said about the business of coming into central Australian communities as an ethical researcher. He talks about old Anangu practices offering us "the proper basis of ethical research practice". Barry claims that our starting point should be "the practice of when, where, and how one camps". In particular, asking where one needs to physically position oneself is critical.

Traditionally, visitors to the Country of another Anangu group would be required to approach from the direction of their homeland, set up camp within view of their hosts, but initiate no contact with them. Then they would wait. Wait for half a day, a full day, or two full days. Only when their hosts approached their camp did it indicate that the visitors were welcome. This is the protocol that our research project has used on field research visits to Papunya (Judd cited in Hawkes, Pollock, Judd, Phipps, \& Assoulin, 2017, p. 26).

Dave: It is also important to explain a little about who we are and what this has to do with what we are writing about.

Len: Dave, you were born in Kaurna country or Adelaide but your moort is from the UK, heh? You and I have known each other since the mid 1980s and we studied youth work together before we each started teaching at university.

Jen: Professor Collard [Len], you describe yourself as Wadjuk Balardong Noongar and we have worked together in different ways since the early 1990s. You, Dave and I met at university during our undergraduate degree in youth work too.

Dave: Jen, you'd describe yourself as a Wedjela (non-Aboriginal) who grew up in Noongar boodjar? Jen: Sometimes! When I'm in the Kimberley I turn into a Gardiya (a non-Aboriginal person) (Muecke, 2014).

\section{Warlbirniny: birniny (In contrast to excavation)}

Jen: Dave, you have had some things to say about the tendency by research organisations to insist on conducting themselves using an "excavation" approach. Can you talk about this?

2 On this occasion we will refer to our relationships with work on Anangu and Yarnangu country. This reflects our personal experiences and the fact that our affiliations are more connected with people from Pitjantjatjara, Yankunytjatjara and Ngaanyatjarra communities. 
Dave: I've come to notice amongst many colleagues and in the culture of universities what I describe as research through "excavation". We come from long traditions of seeing research as an activity that is much the same as mining. We set out as researchers to do some exploration work, prospecting the knowledge terrain, trying to uncover what sits underneath the surface so we can pull it out, bring it back to the academy, carry out some extra on-site production work and then sell it (often in our teaching, research outputs and intellectual market-place). Since the Enlightenment, research has largely been seen as the business of scanning new intellectual territory to discover knowledge to be traded in the global scholarly economy.

Len: This language of "discovery" has made its way into our large research funding bodies. This language is not new for Indigenous people who have had to endure outsiders coming in and digging up stuff as part of colonisation.

Jen: I routinely find myself in meetings with colleagues talking about the importance of "capturing" things like the stories of the old people. I think this metaphor of "capturing" is highly instructive.

Dave: Yes, I remember hearing a talk given by a representative from Google. The presenter made the point that universities largely operate in an old, closed-knowledge economy where "data" is treated as a commodity to be excavated, up-processed and then sold for profit. On this occasion the presenter was trying to convince a bunch of academics that this kind of knowledge economy was outdated, unjust and unpopular with young people. He argued that a feature of many "open-sourced" systems was the need to see consumers (in our case, students) as those we must involve as co-producers through a process of agreement making.

Jen: So how can things be different?

Dave: Len, I wonder whether the Noongar practice of birniny has something to offer us here?

Len: Ah yes, although a simple translation would have it that birniny is "digging, scraping and revealing", I think it is more than this and very much related to research. It has got something to do with the way we hold ourselves on country and the way we go about moving and conducting ourselves.

Birniny, or when you scratch, scrape and dig, you often produce lots of gnarl (sweat). When we birniny we are literally trying to uncover both what is on the surface and also what is underneath. But it is very different from the business of mining or excavating.

The word birniny comes from the word birn, which are particular kinds of plants that you find in the undergrowth in many parts of Noongar boodjar (Noongar country). You usually find birn off the main track and as part of the rich ecology of ground cover and botany that sits between the soil and up to the height of your knees.

Jen: Birn plants are particularly hardy and have prickles and tough foliage that can cut, graze and inflict sores on your legs if you are not careful. From when they were young, koorlangka (children, in Noongar) were taught to walk through country in a particular way to avoid hurting their legs (see Rose et al., 2002). This way of walking demands that you are attentive to both the areas ahead, in proximity to and below your feet. To walk in this way you needs to fine-tune your peripheral vision both vertically and horizontally.

Len: Unlike travelling on a well-worn path or road that is clearly mapped out, koorlangka (children) were taught that our djen (feet) needed be meeyol (eyes), djinanginy (looking), and our kaat katitjin (head is thinking), whether one was wortkoorliny or yarlkoorliny (coming or 
going). Just like an waitj (emu) that is constantly picking, scratching and looking for what is available in the undergrowth, when we walk through the birn we have to move in and around what is offered up by boodjar (country) (Collard, 2007).

Jen: Yes, I love the way the waitj (emu) moves. I often marvel at their feet and the relationship these have to the beak and eyes. It is almost as if the emu has eyes in its toes so that when it walks it lifts its claws, momentarily pausing while the feet take the decision of where to land. Like many other birds the emu's beak is constantly on the go, looking out for opportunities to feed. Of course the emu can't walk backwards but it can turn very quickly.

Dave: How is this different from excavation?

Len: The most important element of birniny is the relationship we have with the place, the knowledge and the people. We were not only taught to birniny through places we were taught to birniny through our relationships with others, struggling and picking our way through the complex systems of community, constantly looking out for the prickly things and being ready to quickly adjust our movements to deal with those around us.

To put it another way, behind the practice of birniny is the importance of constant negotiation with those around you. You can't just wander through country picking up what you like the look of. This is dangerous to you and dangerous for those from that place.

Dave: So the act of birniny is not something you can safely do unless you have knowledge of where you are going and, importantly, you are doing it in conjunction with the bosses for that place?

Jen: This is a nice metaphor for how we might work as researchers, always on the lookout, paying attention to what might lie just out of the corner of our eye and always being prepared to adjust what we are seeing and doing according to the bosses.

Len: What about Anangu practice? Are there ideas that are important for thinking about ethical research from Anangu wangka and ninti (language and knowledge) that could be helpful here?

\section{Kulini, ni (Being and listening)}

Dave: I am reminded of the Pitjantjatjara concept and practice of kuluni when you talk in this way, Len.

Jen: Kulini is often translated as something like "listening". Is this adequate?

Dave: There is a bit of irony in that question. The English-language speaker and conventional researcher brings with them generations of training in trying to quickly replace complex Indigenous ideas and concepts with simple translations. We like to see something and quickly show that we know what it is. Then we are expected to translate this "piece of knowledge" into our way of conceptualizing. Here an idea is an "abstract entity, intact and transmissible from one person (and one culture) to another". Educational philosopher Addelson points out that this way of thinking is premised upon what he calls the notion of "epistemic equality", or the claim that anyone may "know" and quickly become the judging observer (Addelson cited in MacMahon, 2013, p. 22).

Jen: And what is wrong with this premise?

Dave: For a start it often leads to premature conclusions. We also misinterpret things unless we are deeply familiar with Anangu ontology and culture. For example, Liberman (1980, pp. 74-75) 
points out that Anangu can adopt a conversational tool he terms "gratuitous concurrence". This involves people saying "yes", or accept[ing an] outsider's interpretation as a way of "showing respect or avoiding conflict or confusion in conversation".

Len: And if you follow Noongar and Anangu ways of knowing much knowledge exchange is shaped by relationships between people and country (Kickett-Tucker, Bessarab, Coffin, \& Wright, 2017).

For example, in Yolnu knowledge systems from Arnhem Land the djirrikay (boss of knowledge) refuses to pass on knowledge in the absence of conditions that have milmarra (skin-based promise rules) practices in place. This means that one's access to the passing on of knowledge is shaped by one's place in the skin system, one's age and one's place in the arrangements of "promised" relationships. In other words, different people have different knowledge they have access to and a different experience of meaning depending on their relationships. A similar arrangement works in old Noongar katitjin (knowledge systems).

Jen: So listening is an inadequate translation for kulini?

Len: Technically, the English word listening means to use one's ears to hear sounds. If we have been trained in the helping professions or as social researchers we might pick up some allied skills such as honesty, goodwill, empathy, trying to act on what we have heard. However, we also gets lots of training in being disinterested or distant from what our ears hear so that we can claim objectivity. The practice kulini (Noongar use the word "ni") asks us to have much more "skin in the game", both in the English metaphoric sense and the Aboriginal sense as well.

Jen: Kulini perhaps also demands that we get comfortable with disconcertment, celebrating the chance to experience moments of deep existential panic "where you are suddenly caused to doubt what you know" (Verran \& Christie, 2013, p. 53).

Dave: Kulini is way more complex and demanding that simply hearing something. According to the Pitjantjatjara/Yankunytjatjara to English Dictionary (Goddard, 1996, p. 31), the term "kulini" has nine meanings or elements:

1. Listen. To heed

2. Hear

3. Think about, consider

4. Decide

5. Know about

6. Understand

7. Remember

8. Feel

9. Have a premonition from a sensation in the body

You might say kulini demands an array of processes. It includes aural action, corporeal experience, engaging the intellect, drawing on experiences on country and with country, coming into relationships, using epistemologies, and cosmologies and conceptual language. Indeed, to be a master of kulini one would have to consider the possibility of building into our practice premonition, an ability to talk with those who have come before, maybe even listening to the wind (Osborne, 2017, p. 31). 
Jen: This makes sense and this demands much time and discipline. In the sciences and social sciences we would not contemplate sending a researcher into a field like biomedicine, physics, biology, psychology or sociology without asking them to first spend 5 to 10 years "listening" to the language and knowledge of their discipline. Indeed, that is why so many firstyear undergraduate students get lost in lectures, we expect them to listen without knowing the language, epistemology and relationships. In the absence of much preparation we cannot kulini. We may be able to hear the sounds but we cannot kulini.

Len: Kulini is also important for keeping us safe. Unlike the production of other research, Noongar research is closely tied to old and well established Noongar cultural frameworks and practices associated with picking your way safely through knowledge. For example, in (the past) if, for social, spiritual or economic reasons, a neighbouring Noongar group was to travel through to the Perth area, the onus was on them to comply with certain obligations and regulations. At the same time, local Noongar boordier were responsible for the health and safety of visitors (Collard \& Palmer, 2006).

It has always been important to Noongar that visitors take instruction from locals on where to safely go and to not offend djennak (benevolent spirits), quop weirn (good spirits) or Waugal (the old snake spirits), nor move through country without proper introductions. Failure to do so could have devastating consequences on the health and wellbeing of visitors and custodians. Thus the "cultural safety" of visitors was tied up with obligations of both locals and visitors.

Jen: Presenting on behalf of the Combined Noongar native Title Claim, Kingsley Palmer explained it thus:

In Noongar thinking, an owner of country has the right to exclude or grant permission to non-owners to enter and use their land. But he or she also has a duty to share their land with others and a duty to ensure that no harm comes to visitors. The Aboriginal evidence amply demonstrates that Noongar people believe that unknown country is potentially dangerous, because Noongar land is possessed of spiritual potentialities which must either be avoided or knowledgably managed. Ignorance of country is therefore a matter of personal jeopardy. To venture into unknown country is to imperil both yourself and those who depend upon you. This means that, for the most part, Noongar people regard country that is not their own, and therefore which is unknown to them, as country to be avoided (Palmer quoted in Federal Court of Australia, 2006).

Dave: Local Noongar are the ones who are well acquainted with how to protect themselves and outsiders. This means researchers must, for their own safety, have Aboriginal bosses as co-researchers - chief investigators, if you like.

Len: Ni (listening, in Noongar) also involves shifting the kind of ways we listen to recognize the forms Noongar use to communicate. Take for example the way Noongar knowledge is "written". In most of our research practice we have habit of only "listening" to certain kinds of text. Historians, most social scientists, and those involved in heritage and native title, prefer to rely on the archival record. Other researchers seek out work that has been written and published in academic journals. As my Palyku (language group from the Pilbara region) colleagues Kwaymullina, Kwaymullina, Terra Rosa Cultural Heritage Management, and Butterly (2013) point out, Indigenous knowledge agents often prefer other genres such as speaking, poetry, song, dance, film, narrative and creative writing, visual art, and performance. Kaurna, Narungga and Ngarrindjeri scholar Lester Rigney also point out that this work has recently shaped the way "Indigenist" research is being conducted (Rigney, 1999), so that Indigenous content, form and voices are more privileged and honoured (Rigney, 1999; Kuokkanen, 2000; 
Moreton-Robinson \& Walter, 2009). Sami academic Rauna Kuokkanen points out that "Indigenous epistemes have to be recognized as a gift to the academy" (Kuokkanen, 2000, p. 65). Therefore, it's imperative that researchers seek out a range of Indigenous sources, set out in a range of styles and genres, perhaps even those that don't appear heavily "analytical" (Kwaymullina et al., 2013, p. 9).

\section{Ngapartji ngapartji, malparara and gnulla koorliny (Going along together)}

Jen: Part of the tradition of an excavation approach to research is that people who possess knowledge are mostly treated as either objects of the gaze of social science or those who need to be subject to the directions of the investigators.

Dave: Yes, as researchers we are largely taught to deal with human beings using the approach to relationships that Martin Buber describes as "Ich-Es" or an "I-It" encounters. Here the researcher (the "I" in the relationship) confronts and qualifies an "It", treating them as an object. In this kind of relationship we treat other things, people, data, as objects to be used and experienced. This form of objectifying the Other frames "them" in terms of how they can serve the interests of the research. In subtle ways, through referring to people as participants, subjects, interviewees, "the community", a distance is created between Indigenous people as knowledge agents and the researcher as expert and knowledge producer (Buber, 1937).

Jen: How can we do otherwise?

Len: Well let's look at some Noongar and Anangu concepts and practices for instruction.

Doing business with knowledge in Noongar ways has long involved an exchange where the parties gnulla koorliny (go along together). Part of this involves baranginy (bringing or carrying) something to exchange. You don't just take away things you need to baranginy something with you. It might be yongka (kangaroo), mamang djerang (whale fat), boya (stones), or dowark (hitting stick). At the most fundamental, when our old people came together there was always sharing of food that went on. Barry Judd (in Hawkes et al., 2017, p. 26) confirms that this is still the way you do business with Anangu. Now, when we have meetings with family from that side and this side we always make sure we take things like kangaroo tail, plenty of steak, bread and other gifts for the bosses from that place.

Jen: Making sure that the old people are taken care of in other ways is important too. Being able to make a kapati (cup of tea) is way more important in my view than mastering SPSS or some other research tool. If you are not prepared to spend plenty of time signalling your respect for the old people by seeing that their needs are met then you fail your first test in ethical research (Ober, 2017).

Dave: The Anangu concept ngapartji ngapartji is instructive here. This idea and practice is variously translated: "in turn, in turn", or "I give, you give in return" (Castejon et al., 2014; Edwards, 2014).

However, there appears little in the English language that adequately translates "ngapartji ngapartji". Unfortunately, most tend to draw upon modernist ideals and mistakenly assume a kind of market-driven exchange in people's social worlds where one needs to immediately return a favour for a favour, or immediately reciprocate a good turn. As Sennett (2002) points out, this kind of arrangement causes the termination of social connections. The symmetry of exchange (with its obsessions with equality and immediacy) results in people lacking any means of being socially bound to each other. 
Len: Noongar would use the terms yoorl buranginy (bring it or take to) and woort buranginy (grab it and take off) to describe the interplay between bringing something to the table and taking something away.

Jen: Perhaps the English idea of the "gift" takes us a little closer to the Pitjantjatjara concept of "ngapartji ngapartji". In contrast to market exchange, a gift economy obligates people to one another, producing conditions that see people reciprocating their debt. According to Mauss (1967), the gift creates an economy not of altruism but of debt so that gifts must be eventually returned and their value matched. However, the key here is that the gift may not return precisely to the original giver. Rather, a gift moves in a circle, with at least three people needed for the gift economy to work. In a classic gift economy the gift exchange moves in complex directions, moving "from one hand to another with no assurance of anything in return" (Hyde, 1983 , p. 11). In this way, the gift draws us into a mutual dependence upon those involved in the exchange, a formal give-and-take that forces us to acknowledge our participation in and dependence upon each other. It also forces us to respond to those around us, those who are "other" but with whom we are bound, as part of ourselves, not as a wam (stranger or alien).

Len: Can you provide examples of how this can get put into practice in research?

Jen: I like the approach taken by Ngaanyatjarra Pitjantjatjara Yankunytjatjara Women's Council called the malparara way of working (Woods et al., 2000, pp. 91-99). In the Ngaanyatjarra Pitjantjatjara Yankunytjatjara context "malpa" means "friend", and "malparara" means "a person going along with a friend or companion". Malparara is used to describe the process of two people, one Indigenous and one non-Indigenous worker, working together, directly along side of each other.

If we applied this approach to research we would often have to rethink what we employ researchers to do. We may choose some Indigenous workers because of their research expertise in matters to do with culture, their seniority, knowledge of local language, relationship to local kids and skills in relation to keeping people culturally safe. These would be researchers who know the country, know the families, understand local politics, and are exceedingly qualified in terms of Indigenous law and culture. The non-Indigenous researcher may be recruited because they have specific professional skills that relate to western knowledge.

For example, they would normally have formal training in one area of western knowledge, such as nutrition, physiotherapy, anthropology, education, or social policy. These people are also competent at writing, dealing with funding, have knowledge of other "mainstream" services and the culture of government and university policy.

This approach to research is premised upon the idea that the skills, knowledge and community affiliations of one person or people from one cultural domain are inadequate for doing all of the research work and resolving challenges that are encountered in doing the research.

Len: This sounds to me a lot like how things work in Indigenous cultural domains. In my experience, a job taken on in a community setting would normally involve at least a couple of Indigenous people coming together to work on things. This happens because it is more efficient and there is often a need to negotiate across at least two different cultural or familial domains. Noongar could describe this as "gnulluk dabakarn koorliny" (two going along slowly together).

\section{Quop karnya and kanyirninpa (Respectfully passing on knowledge)}

Dave: Len and Jen, can I ask you to talk more about the place Indigenous manners has in ethical research with Indigenous Australians? 
Len: The word karnya means good manners or good moral integrity and sensibilities. Koondarn is another word that implies sensibility and good ways of conducting yourself. If someone says that you got no koondarn then they are saying you have no manners, you are behaving in a manner that is out of order.

Jen: So how do these words contribute to our understanding about how we can be ethical in our research?

Len: As a kid when I was growing up koondarn was related to shame. Karnya is sensibility or having sense. Nowadays many young Noongar use the word karnya to mean shame but it was always more about having respect and seeing to it that knowledge gets passed along with integrity.

Jen: So reciprocal systems of obligation are at the heart of respect or karnya? This reminds me of the importance in Western Desert ontology of the obligations that come with age to nurture those who "come along after" (Myers, 1991, p. 211). Brian McCoy (2008, p. 22), who writes from a strong ethical position of involvement in community development with Kukatja (a southern Kimberley Aboriginal group), draws on the Western Desert concept of Kanyirninpa.

Len: Kanyirninpa sounds like a word that is similar to the Noongar word karnya. What does that mob mean by Kanyirninpa?

Dave: As I understand it, Kanyirninpa is expressed in a number of interconnected ways. It includes the practice of nurturing the young through law and life. It particularly gets used to describe older people taking responsibility and offering protection for those they hold. It involves relationships of teaching and learning where older people help young people "grow up the right way" (McCoy, 2008, p. 22). McCoy (2008, p. 28) also explains that Kanyirninpa or "holding" young people is an act of exercising respect towards others, creating conditions to reinforce social bonds and social obligations (see also Palmer, 2012 for a description of how this plays out in a remote-area community development project).

Jen: So how can this get put into research practice?

Len: Well, one critical thing we have to get much better at is finding a place for young people in our research work and using research projects as one means of encouraging work across the generations. Dave you have been involved in some work that is doing this well.

Dave: I really like some of the models that have been used by ranger teams across northern and central Australia where younger rangers and school kids are becoming involved in the collection of "data" with and from elders and middle-aged people, using dynamic and interesting digital platforms. Through the use of things like film and geospatial tablets young people are bringing their interest and expertise in new and state of the art information technology with senior people's knowledge of old stories, songs, practice and language (Kral, 2010a, 2010b).

Jen: Here the use of new technology is important in a number of ways. Young people are now using multimedia appliances such as stills cameras, video cameras, IPods and MP3 players and other multi-functional devices. They are also operating "user-friendly" applications for post-production such as iMovie, iTunes, iPhoto, GarageBand and Animation Apps. Although not everyone has access, technology has become fast, accessible, highly portable and more publicly available (Kral, 2010a). This world is "symbolic-rich, language-saturated and technologyenhanced" (Hull, 2003, p. 232). Perhaps most importantly, new media also affords the renewal of old processes of intergenerational exchange with Indigenous young people finding spaces to take on leadership and critical roles in recording, learning and producing Indigenous knowledge (Berryman \& Macfarlane, 2017). Increasingly, other generations are cherishing young people's 
take-up of this role, particularly when they act in ways that help them negotiate the spaces between old knowledge and new technology (Buchanan et al., 2016).

\section{Wangkiny (Yarning and analysis)}

Dave: So to talk about ethics in research in the absence of talking about and using wangkiny (language) is unhelpful? Len, can you say some more about this?

Len: I often see words like "respect", "reciprocity", "equality", "informed consent", "responsibility", and "integrity" used by those involved in research with Indigenous communities. These are important ideas but they can sometimes mean little or different things to community people. This is another reason we should look to Indigenous languages for concepts and ideas as the leading language if we are to understand how researchers need to conduct themselves with communities (see Ober, 2017 for an example of the use of the Aboriginal English concept of "Kapati Time").

Of course, the words of the Indigenous communities we work with, the intent and meaning are absolutely essential (see Trudgen, 2000). They are what drive knowledge and knowledge sharing. That is how we hold our knowledge. Just as bio-medical science, economics, zoology and all the western sciences hold their knowledge in their strange and exotic languages, so do Aboriginal knowledge systems.

Other Indigenous groups have been making this point when they talk about research. For example, Māori scholars like Linda Tuhiwai Smith spend much time fleshing out how to carry out what she calls kaupapa Māori research, research that starts from a Māori philosophical base. This approach takes tikanga Māori (a Māori way of doing things) as its first order of analysis and method. Critical here is that researchers use te reo Māori (Māori language) as their means of communicating, research practice, ethical frame and means of analysis (Smith, 1999).

Jen: Using local language in your practice is an important way of recognizing many of the elements that are important to community. Words like boodjar (country), moort (family and relationships), katitjin (Noongar knowledge), kura, yeye, boorda (the connection between the past, present and future) are all important ideas that better set out how to behave for those working with Noongar than do English concepts.

Dave: What do we do if we don't have any language, Len?

Len: Two things: 1) work with language speakers as translators and co-researchers and 2) start to learn. And make sure you apply ngapartji ngapartji here. People acting in these roles as not just assistants, they are co-researchers, even chief investigators.

Jen: In a way, a first-order ethical obligation for researchers is to recognize where they don't have language so that they can do something about this. Respectfully learning language can also be an important way for non-Aboriginal researchers to find an ethical place for themselves. When asked whether a non-Indigenous researcher should carry out kaupapa Māori, researchers Bishop and Glynn (1999) answer in the affirmative - particularly if the researchers position themselves as allies and invest in building their te reo Māori (Māori language).

Len: So for all researchers in Noongar boodjar (Noongar country), you need to learn Noongar as part of your moral, ethical and mutual respect.

Jen: Words have long, deep and secure foundations. In our case the language of the south west of Australia has come to exist over 60,000-plus years to articulate how to live and do 
community in this part of the world. English is much younger, has not come from here and has emerged in a different set of communities to explain and achieve things in a completely different context. Most importantly, English is an introduced language for Noongar and not always the most comfortable language to carry knowledge, practice and insight.

Len: Yes, when I talk to other Noongar about research and try and explain the concepts others use to explain what they are trying to do and the ethical dimensions, I have always struggled to try and articulate clearly what these Wedjela (non-Aboriginal) words and terminologies mean.

I have found it much more productive, useful - let's call it empowering and convincing - when I talk to Noongar using Noongar words and concepts. At the same time this gives me a chance to affirm my relationship with those Noongar, whether it be a demmangur (grandparent), kongk (uncle) or maamyok (aunt) or other members of my moort (family).

Dave: Language is how we hold not just our knowledge but also our ways of being. We hold our ontologies, knowledge systems, behaviours, the cultural protocols. Indeed, the words probably shape the way we hold our bodies.

The history of colonization in places like Australia is the history of outsiders destroying local language and ways of speaking. As Eve Fesl says, one of the first acts of outsiders in Australia was to take away local people's words and right to speak. The rich and deeply instructive languages of over 250 groups across the continent were replaced by words that usually had groups like Noongar being forced to identify themselves by generic terms such as "native", "Aborigine", "half-caste" and now "Indigenous" (Fesl \& Mumewa, 1993).

Len: I would suggest that our language also holds deep clues about how we can go about our research business. The work of Māori scholars Angus and Sonja Macfarlane is one powerful example of this. In setting out what an ethical research process looks like, they draw from te reo Māori, positing that method should be shaped by the following six practices from tikanga Māori (Māori way of doing things):

1. Whanaungatanga - building and maintaining strong relationships grounded in mutual trust, protection of Māori knowledge and care between those involved.

2. Whaiwāhitanga - ensuring participation, co-design of the research and power and benefits are shared.

3. Tātaritanga - listening; thinking; shared meaning-making, careful analysis of the data, and checking of conclusions.

4. Manaakitanga - affection towards others and ensuring the welfare and mana (status and position) of people is maintained through respectful interaction and acknowledgement of the source of knowledge.

5. Rangatiratanga - supporting people to maintain autonomy and control over their involvement in the research.

6. Aroha-maintaining the connection to the kaupapa (knowledge system) and approaching work with an intention of love, kindness and respect (Macfarlane \& Macfarlane, 2015; Macfarlane, 2012; Vaioleti, 2006).

\section{Dabakarn dabakarn and wanyu (Steady, steady)}

Jen: This is also why it is important for outsiders to come into their research work with Aboriginal communities gently and quietly. Here I really like the Noongar idea of dabakarn dabakarn. This means to go along gently, quietly and steady. 
Unlike those of us trained in the Enlightenment traditions of research, Aboriginal knowledge systems recognize that we cannot "discover" knowledge, it can only be revealed and shared (Hall, 2017, p. 73). Time and patience is really important here.

Dave: This reminds me of the Anangu concept of wanyu. If I understand this idea, it means that people are being asked to "wait a while" or slow down so that a considered response can be offered. Lisa Hall elaborates:

(Wanyu) carries epistemologically complex understandings and can be interpreted in many ways including: waiting, giving space, waiting for the right time, not filling up all the space, being patient and waiting until the other person feels ready. While it might be perceived as a passive term where nothing is happening, it is often quite an active space of preparation and foreshadowing. (Hall, 2017, p. 76)

Dabakarn dabakarn or wanyu creates a space for a range of things to happen. It allows researchers to see that good communication can happen. It helps those involved in the work to feel involved, ready and prepared. It is a very practical way of allowing a respectful relationship to grow.

Len: To go along dabakarn dabakarn involves not only listening to what people say but also noticing what is happening with people's bodies, what is happening outside and what is happening between people. This doesn't mean that you ignore your training or your ideas but to go along dabakarn dabakarn demands that you shift your speed and the way you "walk".

Part of going along dabakarn dabakarn involves "reading the play", watching what is happening and being ready to respond. It doesn't mean that you do not move quickly when you need to. In fact, dabakarn dabakarn is a way of preparing you to kert kert djakoorliny (jump quickly into action). Dave, you played Australian Rules Football so you recognize how you move like this.

Dave: Yes, a number of times I have been told by cultural bosses to play "half-back flank". Many people think this is just a defensive position but when I was young I learnt that my job involved both being prepared to receive a handball (having the ball passed) from a key player by stepping into action from slightly behind the play. As one senior cultural boss from the Kimberley region has put it, "you have to sit behind us bosses in the circle and take directions. You cannot cut in front and jump into the circle but when we signal to you the handbrake has to come right off and you have to step up."

\section{Noongarpedia: An example}

Dave: Jen, you and Len have been working on a project called Noongarpedia (see Buchanan et al., 2016). Can you talk about how some of these ideas have shaped this research project?

Jen: Noongarpedia ${ }^{3}$ is a research and development project that has been running for about four years. It has involved using Wikipedia as a platform to support the use and reinvigoration of Noongar knowledge and language. It has included academics, language teachers, children, young people and community groups to both create Noongarpedia entries as a way to learn, pass on, and make public Noongar knowledge, and create relationships across the generations (Collard et al., 2017).

Built into the fundamental elements of this project is the importance of using and passing on Noongar knowledge and language. In this way wangkiny is both the thing we are attempting to support and the tools we need to use to work with community.

3 Visit the site at: https://incubator.wikimedia.org/wiki/Wp/nys/Main_Page 
Len: Some Noongar and non-Noongar have been critical about Wedjela learning language, claiming that it is another act of cultural appropriation. As a Wedjela involved in this project can you say some things about learning Noongar?

Jen: I am very sensitive about this. I get nervous and language regeneration is complicated.

However, two of the three chief investigators are Noongar professors. Noongar language is central to the work. This means that an integral part of me showing my respect and doing my job is to build my Noongar language skills. On the other hand, I am very aware of the sensitivities and pain that many Noongar experience because their families were stripped of their access to language.

If I were to show off my language skills it would be very cruel and insensitive.

Dave: So perhaps rather than asking "should a Wedjela learn Noongar language?" we might ask "how should Wedjela learn and practice Noongar language"? Combining listening and being humble is important.

Len: Important here is what Noongar call ni (deep listening) and karnya (respect) or what Anangu call kulini and kanyirninpa. Sometimes the respectful thing to do is be quiet, sometimes it demands that we speak up.

One of the things we discovered is that setting up a pedia demands that you engage deeply with a knowledge system. The people at Wikimedia Australia ${ }^{4}$ who have taught us how to use the platform have also made it clear that a pedia is not simply a list of words; it involves the creation of a free, deep-knowledge platform. For example, we have had to build a framework around which people's entries sit. The technical instructions that people are offered by the pedia were even shaped used Noongar words. This is something that has evolved as people add content to the Noongarpedia.

Dave: One of the striking features of this works is the way that is draws people into becoming both "consumers" and "producers" of Noongar knowledge. What is interesting is that the work points to the need to consider the part cultural production and performance plays in Noongar knowledge transmission and the possibilities that emerge for Web2.0 platforms to support Indigenous cultural maintenance, reformation and transmission. Noongarpedia not only provided the means to record Noongar knowledge, it simultaneously helped to activate Noongar and others in the performance of that culture (Buchanan et al., 2016).

Jen: In contrast to earlier Web1.0 or pre-Web production of knowledge (where the producers and holders of knowledge simply instruct and pass on knowledge and information to passive consumers), many of the new platforms encourage the creation of what has become known as "prosumers", or those who consume and produce simultaneously (Kutay \& Green, 2013).

Len: This has much more in common with old systems of knowledge transmission where young Noongar and Anangu are encouraged to learn by doing, at the same time having knowledge given to them by the old people while they perform it to others.

Dave: This reminds me of the term kanyirninpa (respectfully passing on knowledge across the generations). How did you do this?

Jen: We worked with many schools, inviting knowledge holders to visit and offer a workshop on some element of Noongar knowledge. Using iPads and laptops we would then have the

4 Wikimedia Australia, Inc. $®$ is an independent and charitable organisation, recognised by the Wikimedia Foundation as an official chapter of the global organisation. It seeks to promote involvement in Wikimedia projects and offers open access and participation by all in the collaborative creation of free cultural works in Australia. 
kids learn how to become "wikimedians" (those who edit and produce content that then gets uploaded). Finally, as part of their classroom work, the kids were invited to post something they had learned from the earlier session. Often kids would check in with parents, uncles and aunties and grandparents, seeking their advice and input so that extra content could be produced that was specific to family history and knowledge.

Len: We also used this process with four different groups of tertiary students and a team of rangers.

One of the consequences of carrying out a research exercise in this way was that Noongarpedia became more than simply research, it also became what Dave you would call a "developmental" project, something that offered a legacy of ongoing benefit to Noongar. Even though technically the research project funding has finished, the work goes on.

Dave: How does this work?

Jen: It is because we have used a social media platform that has a life of its own after the research. Those that have been introduced to Wikipedia as a tool (and the Noongar version of it we have called "Noongarpedia") can now continue to use it as a way of making public their knowledge of Noongar. For as long as Wikipedia exists the content that has been posted can stay available to anyone that wants to use it.

Dave: So this seems to be a wonderful example of ngapartji ngapartji at work. Built into the project is a system that helps research move away from the old excavation model where the researchers just take from the host community. It provides a great means of reciprocating the gifts that Noongar knowledge holders offer and make public. In a way, it is like a modern version of kanyirninpa where a research project uses social media as a way to encourage the "holding" and passing of knowledge across the generations.

Len: Yes, the idea of gnulla koorliny (going along together) was essential. Without the involvement of older knowledge-holding Noongar, there would be no project. At the same time, young people took on the role of content producers, posting up on the pedia. There were lots of involvement from people in the middle generation who were teacher assistants, parents and of course the research team. These people helped act as interpreters and facilitators of the workshops. The research team was dependent on the involvement of community. We probably could have just posted all of the content that we had researched but that would have limited the amount of content posted, not supported ongoing community use of the pedia, meant that activity on the pedia would have finished when the project finished, and been inconsistent with old Noongar systems of knowledge transmission.

Jen: There were some features that are like the malpararra system. Those different groups involved in the project had different skills, different access to knowledge and, in some cases, different roles to play. Most of the older knowledge holders have little skill in using new digital platforms but they have great knowledge of moort (family), boodjar (country), wangkiny (language) and katitjin (old stories). The kids had little old knowledge of these things but had great interest in and dexterity with social media. The middle group was often terrific at translating.

Len: One of the other wonderful things about the project is that the pedia platform allowed us to go along gently, posting a little bit at a time, testing out how things were travelling and giving people from different points of ability time to pick up their skills. For those of us who were nervous about suddenly making Noongar knowledge available publicly, Wikimedia allowed us to experiment with making the site available as an "incubator" so that we could see how it went without making it fully available. Much of the work in schools went along dabakarn dabakarn (steady and slowly), allowing us to wait awhile until those who were uncomfortable caught up and saw what it would look like. 


\section{Boordawan (Conclusion)}

Jen: We have been asked to talk about ethical practice in research with Indigenous communities in Australia. I can imagine that some people would be expecting us to talk about the history of colonial history and the systematic marginalization of Indigenous communities in research, the importance of researchers decolonizing their minds and reflecting on their values and positions of advantage, or establishing good dialogue and processes of "engagement" that see them regularly consulting with leaders in the communities with whom they work. Others would be looking for a discussion of principals such as social justice, self-worth, self-determination, inclusion and equity (see Nakata, Nakata, Keech, \& Bolt, 2012, for a useful discussion of the variety of approaches to thinking about Indigenous research).

Len: Yes, and we could talk about these ideas at some other point. However, the first observation I would make is that for as long as I have been involved in research I have found these ideas difficult to pin down, usually out of reach of many Noongar and Anangu (see Anderson, 1996, for a discussion of the limits of conventional research approaches with Indigenous communities).

What we have tried to do in this chapter is turn to some Noongar and Anangu discourse and concepts that are associated with the business of knowledge exchange. We have started to talk about the place of the following practices: wangkiny boordier (talking and yarning to the bosses), birniny (digging and scratching), kulini (being and listening), ngapartji ngapartji, malpararra, gnulla koorliny (going along together and reciprocating), quop karnya, kanyirninpa (respectfully passing on knowledge) and dabakarn dabakarn, wanyu (steady, steady).

Dave and Jen: Kaya boordawan (yep, that's right, talk later).

Len: Kaya boordawan.

\section{Biographies}

Jennie Buchanan grew up in Noongar boodjar. She trained and practiced as a youth and community worker and has since worked for many Aboriginal community-controlled organisations and a range of universities. She has recently been involved in a project that involves the creation of a Noongarpedia to support Indigenous knowledge and language transmission.

Len Collard is a Wadjuk Balardong Noongar from the south west of Western Australia. He is a Professor of Indigenous Studies at the University of Western Australia and has served on the university human ethics committee. He has carried out research work on Noongar language, place names, culture and knowledge systems. He is presently working on research concerned with Aboriginal men and fathering practice.

Dave Palmer was raised in Adelaide but has lived in Western Australia for the last 30 years. His family comes from Great Britain and he is a Senior Lecturer in Sociology and Community Development at Murdoch University. His research work takes him to the west Kimberley, west Pilbara, the south west of Western Australia and central Australia, supporting Indigenous community-controlled projects. 


\section{References}

Anderson, I. (1996). Ethics and health research in Aboriginal communities. In J. Daly (Ed.), Ethical Intersections: Health Research, Methods, and Researcher Responsibility (pp. 153-65). St. Leonards, NSW: Allen \& Unwin.

Barlo, S. (2017). Lessons from participants in decolonizing research. Learning Communities: International Journal of Learning in Social Contexts. Special Issue: Decolonising Research Practices, 22: 16-25.

Berryman, M., \& Macfarlane, S. L. (2017). Hopes for the future: Indigenous knowledge as an enabler of potential. American Journal of Indigenous Studies, 1: SI9-S127. Retrieved from http://www. asraresearch.org/ajis-special-issue-vol-1-no-2/

Bessarab, D., \& Ng'andu, B. (2010). Yarning about yarning as a legitimate method in Indigenous research. International Journal of Critical Indigenous Studies, 3(1) 37-50.

Bishop, R., \& Glynn, T. (1999). Culture counts: Changing power relations in education. Palmerston North, New Zealand: Dunmore Press.

Buber, M. (1937). I and Thou. London: Charles Scribner's Sons.

Buchanan, J., Collard, L., Cumming, I., Palmer, D., Scott, K., \& Hartley, J. (2016). Noongar boordier gnulla katitjin - The influence of Noongar knowledge. Cultural Science, 9(1): 37-53.

Castejon, V., Cole, A., Haag, O. \& Hughes, K. (Eds), Ngapartji ngapartji: In turn in turn: Ego-histoire, Europe and Indigenous Australia (pp. 259-270). Canberra: ANU Press.

Collard, L. (2007). Wangkiny ngulluck Nyungar nyittiny, boodjar, moort and katitjin: Talking about creation, country, family and knowledge of the Nyungar of south Western Australia. In S. Morgan, T. Mia, \& B. Kwaymullina (Eds.), Speaking from the heart: Stories of life, family and country (pp. 261-278). Fremantle: Fremantle Arts Centre.

Collard, L., Hartley, J., Scott, K., Bracknell, C., Lucy, N., Buchanan, J., \& Cumming, I. (2017). Could a "Noongarpedia" form the basis for an emerging form of citizenship in the age of new media? In A. Garmen, \& H. Wasserman (Eds), Media and citizenship: Between marginalisation and participation (pp. 159-180). Cape Town, South Africa: HSRC Press.

Collard, L., \& Palmer, D. (2006). Kura, yeye, boorda, Nyungar wangkiny ngulla koorlangka: A conversation about working with Indigenous young people in the past, present and future. Youth Studies Australia 25(4): 25-32.

Edwards, B. (2014) A Personal journey with Anangu.history. In ab-Original Journal of Indigenous Studies and First Nations and First Peoples' Cultures, 1(1): 41-60.

Federal Court of Australia. (Wilcox J). (2006). Bennell v the State of WA. 19 September 2006 [2006] FCA 1243.

Fesl, E., \& Mumewa, D. (1993). Conned! St. Lucia, Qld: UQP.

Freire, P. (1986). Pedagogy of the oppressed. New York: Continuum.

Goddard, C. (Ed.) (1996). Pitjantjatjara/Yankunytjatjara to English Dictionary (Rev. 2nd Ed.). Alice Springs: IAD Press.

Hall, L. (2017). Anma, marpla and ngapartji ngapartji: Insights into how to do research together in "good faith". Learning Communities: International Journal of Learning in Social Contexts. Special Issue: Decolonising Research Practices, 22:70-80.

Hawkes, G. L., Pollock, D., Judd, B., Phipps, P., \& Assoulin, E. (2017). Ngapartji ngapartji: Finding ethical approaches to research involving Indigenous peoples, Australian perspectives. ab-Original Journal of Indigenous Studies and First Nations and First Peoples' Cultures, 1(1): 17-41. 
Hull, G. A. (2003). At last: Youth culture and digital media: New literacies for new times. Research in the Teaching of English, 38(2), 229-233.

Hyde, L. (1983). The gift: Imagination and the erotic life of property. New York: Vintage Books.

Judd, B. (2014). From Paris to Papunya: Postcolonial theory, Australian Indigenous studies and "knowing" "the Aborigine". In V. Castejon, A. Cole, O. Haag, and K. Hughes (Eds), In turn in turn: Ego-histoire, Europe and Indigenous Australia (pp. 143-158). Canberra: Australian National University.

Kickett-Tucker, C., Bessarab, D., Coffin, J., \& Wright, M. (2017). Mia Mia Aboriginal community development: Fostering cultural security. Port Melbourne, Vlc.: Cambridge.

Kral, I. (2010a). Generational change, learning and remote Australian Indigenous youth. Canberra: CAEPR.

Kral, I. (2010b). Plugged in: Remote Australian Indigenous youth and digital culture. Canberra: CAEPR.

Kuokkanen, R. (2000). Towards an "Indigenous paradigm" from a Sami perspective. Canadian Journal of Native Studies 20(2): 411-436.

Kutay, C. and Green, R. (2013). In L. Ormond-Parker, A. Corn, C. Fforde, K. Obata, \& S. O'Sullivan (Eds), Culture online. Information Technology and Indigenous Communities (pp. 89-103) Canberra: AIATSIS.

Kwaymullina, A., Kwaymullina, B., Terra Rosa Cultural Heritage Management \& Butterly, L. (2013). Living texts: A perspective on published sources, Indigenous research methodologies and Indigenous worldviews. International Journal of Critical Indigenous Studies, 6(1): 1-13.

Liberman, K. (1980). Ambiguity and gratuitous concurrence in inter-cultural communication. Human Studies, 3(1), 65-85.

Macfarlane, S. L. (2012). In pursuit of culturally responsive evidence based special education pathways in Aotearoa New Zealand: Whaia ki te ara tika (Unpublished doctoral thesis). University of Canterbury, Christchurch, New Zealand.

Macfarlane, S. L., \& Macfarlane, A. H. (2013). Culturally responsive evidence-based special education practice: Whaia ki te ara tika. Waikato Journal of Education. Te Hautaka Mâtauranga o Waikatovol Vol 18, Issue 2. p. 65-78.

MacMahon, K. (2013). The promise of milmarra. Learning Communities: International Journal of Learning in Social Contexts, 12: 18-23.

Mauss, M. (1967). The gift: Forms and functions of exchange in archaic societies (I. Cunnison, Trans.). New York: WW Norton.

McCoy, B. F. (2008). Holding men: Kanyirninpa and the health of Aboriginal men. Canberra: Aboriginal Studies Press.

Moreton-Robinson, A., \& Walter, M. (2009). Indigenous methodologies in social research. In M. Walter (Ed.), Social research methods (pp. 1-18). Melbourne: Oxford University Press.

Muecke, S. (2004). Ancient and modern: Time, culture and Indigenous philosophy. Sydney: University of New South Wales Press.

Muecke, S. (2014) Turning into a gardiya. In V. Castejon, A. Cole, O. Haag, \& K. Hughes (Eds), Ngapartji ngapartii: In turn in turn: Ego-histoire, Europe and Indigenous Australia (pp. 259-270). Canberra: ANU Press.

Myers, F. D. (1991). Pintupi country, Pintupi self: Sentiment, place and politics among Western Desert Aborigines. Berkeley: University of California. 
Nakata, N. M., Nakata, V., Keech, S., \& Bolt, R. (2012). Decolonial goals and pedagogies for Indigenous studies. Decolonization: Indigeneity, Education \& Society, 1(1): 120-140.

Ober, R. (2017). Kapati time: Storytelling as a data collection method in Indigenous research. Learning Communities: International journal of Learning in Social Contexts. Special Issue: Decolonising Research Practices, 22: 8-15.

Osborne, S. (2017). Kulini: Framing ethical listening and power-sensitive dialogue in remote Aboriginal education and research. Learning Communities: International journal of Learning in Social Contexts. Special Issue: Decolonising Research Practices, 22: 26-37.

Palmer, D. (2012). We got to look at our old people, use a different school: The Yiriman Project, going back to country and bringing out stories across generations in the Kimberley. In P. Westoby, \& L. Shevellar (Eds), Community-based education and training: Learning and mobilising within community development work (pp. 41-54). Surrey, England: New Society Publishers.

Rigney, L. (1999). Internationalization of an Indigenous anticolonial cultural critique of research methodologies: A guide to Indigenist research methodology and its principles. Wicazo Sa Review (Emergent ideas in Native American Studies) 14(2): 109-121.

Rose, D. B., D'amico, S., Daiyi, N., Deveraux, K., Daiyi, M., Ford, L., \& Bright, A. (2002). Country of the heart: An Indigenous Australian homeland. Canberra: Aboriginal Studies Press.

Sennett, R. (2002). Respect: The formation of character in an age of inequality. London: Allen Lane.

Smith, L. T. (1999). Decolonising methodologies: Research and indigenous peoples. Dunedin, New Zealand: University of Otago.

Trudgen, R. (2000). Why warriors lie down and die: Towards an understanding of why the Aboriginal people of Arnhem Land face the greatest crisis in health and education since European contact. Darwin: Aboriginal Resource and Development Services Inc.

Vaioleti, T. M. (2006). Talanoa research methodology: A developing position on Pacific research. Waikato Journal of Education 12: 21-34.

Verran, H., \& Christie, M. (2013). The generative role of narrative in ethnographies of disconcertment: Social scientists participating in the public problems of North Australia. Learning Communities: International Journal of Learning in Social Contexts, 12: 51-57.

Westoby, P., \& Dowling, G. (2013). Theory and practice of dialogical community development: International perspectives. London: Routledge.

Woods, W., Wanatjurra, E., Colin, T., Mick, J., Lynch, A. and Ward, N. (2000) 'Atunypa wiru malparara malparara': the strength of working together. In Weeks, W. and Quinn, M. (Eds) Issues Facing Australian Families. p. 91-100. Sydney: Longman. 


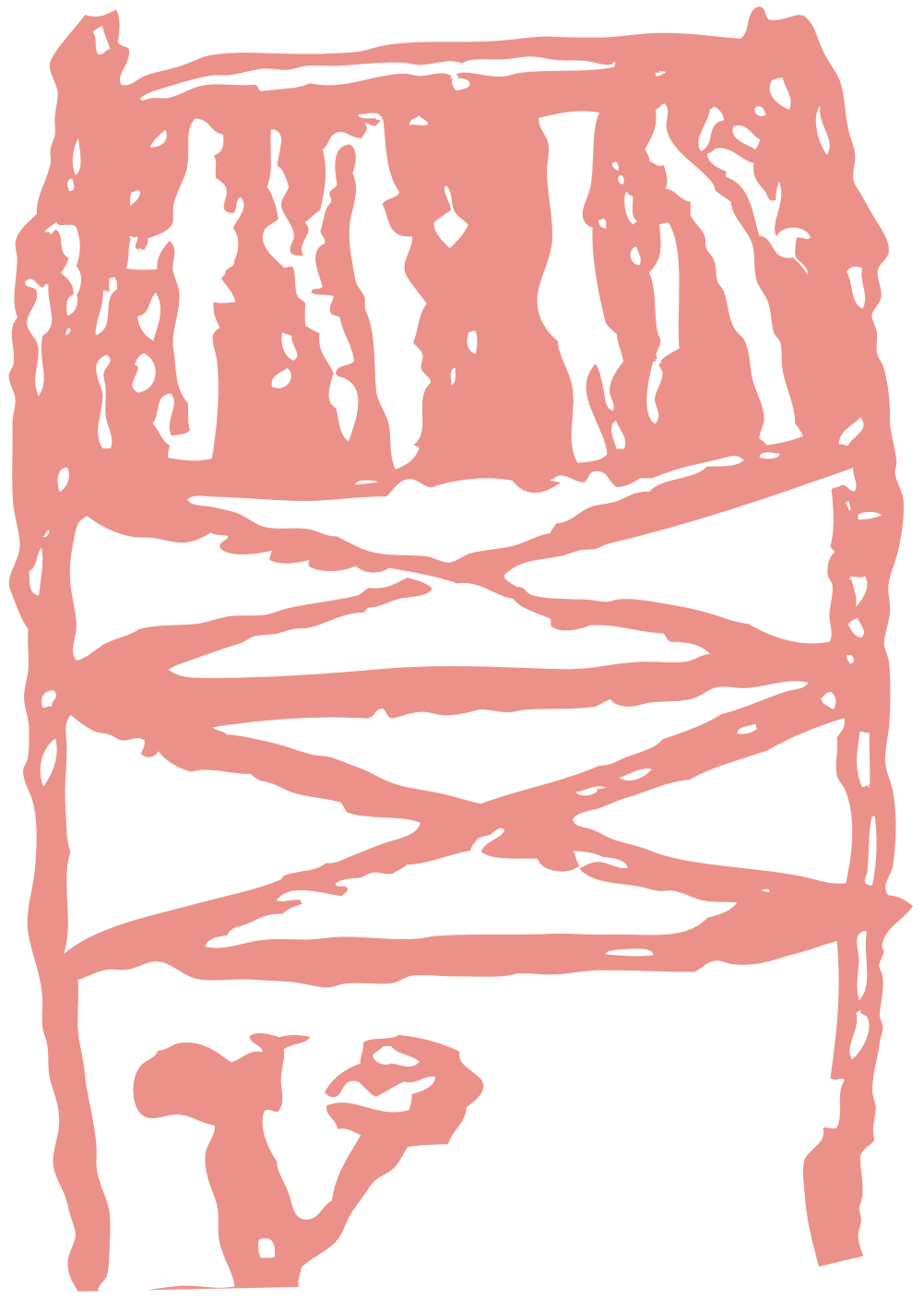

